\title{
Skin Problems among Users of the Urine-Based Fertiliser in Ouagadougou Periurban Areas, Burkina Faso: A Prospective Study
}

\author{
Joseph M. Makaya ${ }^{*}$, Serge Aho², Joseph Wethé ${ }^{3}$, Dayéri Dianou ${ }^{4}$, Nicolas Barro', \\ Alfred S. Traoré1 \\ ${ }^{1}$ Research Center for Biological, Food and Nutritional Sciences, Research and Training Unit, Life and \\ Earth Sciences, University of Ouagadougou, Ouagadougou, Burkina Faso \\ ${ }^{2}$ Epidemiology and Infection Control Unit, Public Hospital of Dijon, Dijon, France \\ ${ }^{3}$ Pan African Agency, Water and Sanitation for Africa, Ouagadougou, Burkina Faso \\ ${ }^{4}$ National Center for Scientific and Technological Researches, Institute for Health Sciences Research, \\ Ouagadougou, Burkina Faso \\ Email: ${ }^{*}$ makaya.joseph7@gmail.com
}

Received 22 October 2014; revised 19 November 2014; accepted 11 December 2014

Copyright (C) 2014 by authors and Scientific Research Publishing Inc.

This work is licensed under the Creative Commons Attribution International License (CC BY).

http://creativecommons.org/licenses/by/4.0/

(c) (i) Open Access

\section{Abstract}

The great challenge for the sustainable use of excreta (urine, faeces) in agriculture is to increase the benefits of these products as resources and decrease the negative effects on human health. The risk of gastrointestinal diseases associated with the use of human excreta as natural fertilisers is well established, while information on skin problems remains largely anecdotal. The objective of this study was to evaluate the prevalence of skin problems among people involved in the handling of the urine used as fertiliser along a productive sanitation system in Ouagadougou periurban areas. A questionnaire was used for each targeted worker to collect data on sociodemographic characteristics, conditions of work and reported health symptoms such as skin burning, itching, eye irritation and paronychia. The exposure measurements were essentially based on field observations. A total of 435 people were interviewed, including 45 workers in urine storage sites, 209 farmers using urine-based fertiliser and 181 control farmers. More than $35 \%$ of site workers reported skin symptoms. For farmers using urine-based fertiliser and their controls, $17.2 \%$ and $26.0 \%$ reported skin symptoms, respectively. Overall, the associations between skin symptoms and the handling of urine used as fertiliser were almost significant $(P<0.06)$. Also, the study showed that these skin symptoms reported by the urine handlers are associated with conditions

\footnotetext{
${ }^{*}$ Corresponding author.
}

How to cite this paper: Makaya, J.M., et al. (2014) Skin Problems among Users of the Urine-Based Fertiliser in Ouagadougou Periurban Areas, Burkina Faso: A Prospective Study. Open Journal of Safety Science and Technology, 4, 178-186. 
of work. Effective preventive measures such as wearing suitable protective equipment and practicing good personal hygiene should be emphasized. This topic needs to be further examined using longitudinal studies.

\title{
Keywords
}

\author{
Human Urine, Fertiliser, Exposure, Hazardous Agents, Skin Problems
}

\section{Introduction}

In order to decrease reliance on chemical fertilisers, human excreta (urine, faeces) are used in agriculture around the world [1]-[3]. In Burkina Faso, urine-based fertiliser was used firstly by truck farmers in Ouagadougou periurban areas, along productive sanitation systems [4]. The main steps in the management of a sanitation system are: urine collection from the eco-toilets (Urine Diversion Dry Toilet), transportation and storage (on a site) before the use as liquid fertiliser. The quality of the urine from these systems was previously evaluated [3] [4].

Human health risks associated with the use of wastewater and excreta in agriculture have been well shown [5]. Although the risk for certain gastrointestinal diseases has been established, the information on other potential human health risks is still largely anecdotal. Studies in many countries with farmers using wastewater suggested a high prevalence of the skin ailments [6]-[8]. In general, causes of these skin problems remained unknown [8] [9].

Also, farmers and workers involved in handling activities (e.g. cleaners) often complain about skin problems caused by various irritants and allergens, including sun [10], biological agents such as bacteria [11] [12] and chemicals such as pesticides and heavy metals [13]-[15]. Some soaps and detergents can damage the skin [16] [17].

The skin is a considerable interface between man and his environment [18]; it is an important portal of entry for hazardous agents and a vulnerable target tissue as well [19] [20]. Colonized by a normal resident flora, the skin is frequently contaminated by pathogens. Staphylococci and enterococci are the most common skin bacterial contaminants [12] [21] [22]. About 20\% of the normal population carries continuously Staphylococcus aureus on the body. This chronic carriage is a risk factor for skin infections [23] [24]. Paronychia a skin infection of the fingers, occurs especially among manual workers. Staphylococci are the main causative agents, but can also be an Enterococcus or gram-negative bacteria [21].

In Burkina Faso, the incidence of skin diseases associated with exposure to wastewater and agricultural inputs (fertilisers and pesticides) is not known. This incidence is probably high for the following reasons: 1) The presence in irrigated water of some hazardous agents [25]-[27]; 2) The large amounts of chemical inputs frequently handled by farmworkers; 3) The use of prohibited pesticides in the agricultural sector [27]; and 4) The non-compliance with protective measures on handling some products in the fields [28].

Ammonia is used to produce chemical fertilisers. It also helps to preserve stored fruits [29]. However, this gas can cause severe skin irritation or burns due to its high solubility in water. Therefore, skin irritation can occur after sweating if the skin is in contact with ammonia, because of ammonia's caustic effect [29] [30]. Irritation due to ammonia can also affect eyes, causing watering and conjunctival ulceration. Glaucoma can occur after a long-term exposure to ammonia [29] [31].

This study was conducted among handlers of the urine used as fertiliser in Ouagadougou periurban areas, Burkina Faso. The main objective was to evaluate the prevalence of skin problems reported by people involved in the urine handling along a productive sanitation system.

\section{Materials and Methods}

\subsection{Research Setting}

The study was conducted in Ouagadougou periurban areas, where a large scale project in productive sanitation was implemented. For a period of three years (2006-2009), the project has equipped around 1000 households with eco-toilets (Urine Diversion Dry Toilets, UDDT). In each sector covered by the project, a productive sani- 
tation system was set up, in which excreta is collected separately via UDDT and are transported and stored on a site before the use as fertilisers in the field. Urine was stored in jerry cans $(20 \mathrm{~L})$ and tanks $(1000 \mathrm{~L})$.

Each filled container was closed for at least 30 days. On average, 600 jerry cans and 15 tanks per site were used to manage the urine stocks. Our study was limited to two sites and conducted for a period of 11 months (February 2011-January 2012). Parameters of interest (pH, ammonia, heavy metals, E. coli, S. aureus, Enterococcus sp.) in urine from the studied sanitation system have been previously measured [3].

\subsection{Study Population}

Two groups of workers along productive sanitation systems were targeted: 1) Handlers of the urine in storage sites, in which the main tasks were collection and transportation of the urine from households to storage sites, and the decanting, cleaning and maintenance of containers; and 2) Farmers using urine-based fertiliser. A control group was integrated in this study, including non-urine using farmers, working in the same conditions as the others. All participants in this study were volunteers.

\subsection{Data Collection}

The survey on skin problems among targeted groups was preceded by the field visits in order to report the work conditions of people. To do this, forms were filled out at each visit, indicating observations concerning the hygiene practices in urine storage sites, the quality of irrigation water, and the protective measures taken during the urine handling. Data from field visits guided us to formulate relevant items for a questionnaire, which were individually administered at the workplace. The interviews were conducted face-to-face with investigators. The questionnaire was comprised of three parts: 1 ) The first part consists of items to collect sociodemographic characteristics of respondents; 2) The second part includes items relating to the environment and work conditions. These are the questions to find out what activities the person did, frequency of the urine handling, and about protective equipment used when working; and 3) The third part, which includes items relating to recent and/or current skin problems self-reported for the duration of work. Skin burning, itching, eye irritation and paronychia were the health symptoms examined. The location of these symptoms was also required to respondents.

\subsection{Data Analysis}

Statistical analysis of data was performed using the STATA V12.1 (Stata Corp 4905 Lakeway Drive, Texas, USA) software. The variables were analyzed by Chi-square test or Fisher's exact test. A $P$-value less than 0.05 was considered statistically significant.

\section{Results}

\subsection{Description of the Study Population}

In total, 435 people responded to the questionnaire, including forty-five (45) site urine handlers, two hundred and nine (209) farmers using urine-based fertiliser and one hundred eighty-one (181) as control farmers. The sociodemographic characteristics of the respondents are presented in Table 1.

The average age of respondents was about 38 years. Male interviews predominated, with $60 \%$ and $80 \%$ for site workers and farmers respectively. The majority of those interviewed people had a low level of education (primary or uneducated). Among field workers, truck farmers were the most numerous (97\%), followed by flower growers (3\%). For the duration of work, $53 \%$ of site urine handlers had more than 3 years and $20 \%$ had one year or less. About $87 \%$ of farmers had more than 3 years in working.

\subsection{Skin Problems among Targeted Groups}

More than 35\% of site urine handlers have reported skin symptoms (Table 2), including skin burning (8.8\%), itching (22.2\%) and eye irritation (4.4\%). No case of paronychia has been reported. Overall, the association between reported skin symptoms and the handling of urine on storage site was significant $(P<0.05)$.

In farmers, handling and non handling (control) the urine, the percentage of reported skin symptoms were $17.2 \%$ and $26.0 \%$ respectively (Table 2). These health symptoms reported by farmers handling the urine and their controls included, skin burning (4.8\% vs. $7.7 \%$ ), itching (6.7\% vs. $4.4 \%$ ) and paronychia (5.7\% vs. $13.8 \%$ ). 
Table 1. Main sociodemographic characteristics of all respondents.

\begin{tabular}{|c|c|c|c|}
\hline Personal characteristics & $\begin{array}{c}\text { Site urine handlers } \\
n \mathrm{n}=45\end{array}$ & $\begin{array}{l}\text { Urine handling farmers } \\
\qquad \mathrm{n}=209\end{array}$ & $\begin{array}{c}\text { Control farmers } \\
n=181\end{array}$ \\
\hline \multicolumn{4}{|l|}{ Age (year) } \\
\hline $\operatorname{Mean}^{\delta}$ (SD) & $37.1(12.6)$ & $39.9(9.0)$ & $38.6(11.9)$ \\
\hline \multicolumn{4}{|l|}{ Age groups } \\
\hline$<21$ n (\%) & $5(11.1)$ & $7(3.3)$ & $22(12.1)$ \\
\hline 21 - 49 n (\%) & $30(66.6)$ & $163(77.9)$ & 115 (63.5) \\
\hline >49 n (\%) & $10(22.2)$ & 39 (18.6) & $44(24.3)$ \\
\hline \multicolumn{4}{|l|}{ Sex } \\
\hline Male n (\%) & $27(60)$ & $193(92.3)$ & $127(70.1)$ \\
\hline Female n (\%) & $18(40)$ & $16(7.6)$ & $54(29.8)$ \\
\hline \multicolumn{4}{|l|}{ Educational level } \\
\hline High school n (\%) & $0(0)$ & $1(0.5)$ & $0(0)$ \\
\hline Secondary school n (\%) & $10(22.2)$ & 25 (11.9) & $17(9.4)$ \\
\hline Primary school n (\%) & $20(44.4)$ & $73(34.9)$ & $29(16.0)$ \\
\hline Uneducated n (\%) & $15(33.3)$ & $110(52.6)$ & $135(74.5)$ \\
\hline \multicolumn{4}{|l|}{ Farming type } \\
\hline Horticultural n (\%) & l & 206 (98.5) & $173(95.5)$ \\
\hline Ornamental n (\%) & l & $3(1.4)$ & $8(4.5)$ \\
\hline \multicolumn{4}{|l|}{ Duration of work (year) } \\
\hline$<1$ n (\%) & $9(20)$ & $6(2.8)$ & $6(3.3)$ \\
\hline 1 - 3 n (\%) & $12(26.6)$ & $11(5.3)$ & 25 (13.8) \\
\hline$>3 \mathrm{n}(\%)$ & $24(53.3)$ & $192(91.8)$ & $150(82.8)$ \\
\hline
\end{tabular}

${ }^{\delta}$ Values given as mean (SD).

Table 2. Percentage of skin problems reported by respondents.

\begin{tabular}{cccc}
\hline & $\begin{array}{c}\text { Site urine handlers } \\
\mathrm{n}=45\end{array}$ & $\begin{array}{c}\text { Urine handling farmers } \\
\mathrm{n}=209\end{array}$ & $\begin{array}{c}\text { Control farmers } \\
\mathrm{n}=181\end{array}$ \\
\cline { 2 - 4 } Symptoms & $\mathrm{n}(\%)$ & $\mathrm{n}(\%)$ & $\mathrm{n}(\%)$ \\
Overall & $16(35.5)$ & $36(17.2)$ & $47(26.0)$ \\
Burning & $4(8.8)$ & $10(4.8)$ & $14(7.7)$ \\
Itching & $10(22.2)$ & $14(6.7)$ & $8(4.4)$ \\
Paronychia & $0(0)$ & $0(0)$ & $25(13.8)$ \\
Eye irritation & $2(4.4)$ & $0(0)$ \\
\hline
\end{tabular}

\subsection{Occurrence of Skin Symptoms and Work Conditions}

In Table 3, it is shown the incidence rates of skin symptoms related to work conditions in handlers of the urine on storage site. Sixteen $(16)$ workers $(n=45)$ reported skin problems “due to the urine exposure”. In less than one year in working, $50 \%$ and $30 \%$ of them respectively had complained about skin burning and itching. Those who reported eye irritation had more than 3 years in the work. 
Table 3. Incidence rate of skin symptoms reported by site urine handlers.

\begin{tabular}{|c|c|c|c|}
\hline \multirow{2}{*}{ Variables } & Skin burning & Itching & Eye irritation \\
\hline & $\%$ & $\%$ & $\%$ \\
\hline \multicolumn{4}{|c|}{ Duration of work (year) ${ }^{\dagger}$} \\
\hline$<1$ & 50 & 30 & 0 \\
\hline $1-3$ & 25 & 40 & 0 \\
\hline$>3$ & 25 & 30 & 100 \\
\hline \multicolumn{4}{|c|}{ Frequency in urine handling ${ }^{\dagger}$} \\
\hline$\geq$ Twice per week & 75 & 60 & 100 \\
\hline$\leq$ Twice per week & 25 & 40 & 0 \\
\hline \multicolumn{4}{|c|}{ Personal protective equipment } \\
\hline Yes & 100 & 90 & 100 \\
\hline No & 0 & 10 & 0 \\
\hline \multicolumn{4}{|c|}{ Location of skin symptoms } \\
\hline Hand & 37.5 & 25 & 0 \\
\hline Forearm & 37.5 & 50 & 0 \\
\hline Foot & 25 & 0 & 0 \\
\hline Other & 0 & 25 & 100 \\
\hline
\end{tabular}

${ }^{\dagger} P=0.06$.

By handling the urine on storage site, with a frequency of more than twice per week, had given incidence rates of $75 \%, 60 \%$ and $100 \%$ respectively for skin burning, itching and eye irritation (Table 3). Surprisingly, we observed that almost all workers on the urine storage site and who reported skin symptoms had personal protective equipment consisting of a coat with short sleeves, a gas mask, boots and gloves. This data confirms the observations made in the field in that there was a lack of interest in wearing this protective equipment, the poor state and the unsuitability of these protective materials. Skin symptoms mentioned were reported more than once in the concerned site workers. Itching and skin burning were most often located on forearms, hands and feet.

In Table 4, the incidence rates of skin symptoms reported by farmers using urine-based fertiliser are presented.

In farmers handling urine-based fertiliser which reported skin symptoms (26 among 209 in total), about 85\% had at least two years in the work. For these farmers, the frequency of handling urine averaged once per week. More than half of farmers (59\%) did not use a personal protective equipment (Table 4). Skin burning and itching were experienced by all reporting farmers (100\%). For paronychia, 83.3\% of reporting people were truck farmers and $16.7 \%$, flower growers. Overall, the skin burning was most often located on hands and feet, while itching occurred on forearms. Except for paronychia, the other skin symptoms were experienced more than once by almost all reporting farmers. Observations in the field have shown that the farmers' existing protective equipment was not worn automatically during the urine handling. The reasons for this disinterest on wearing personal protective equipment have not been clearly given. Also, in the opinion of almost all farmworkers interviewed, "the quality of the water used for irrigation was good, since it was extracted from wells and dams". Taking into account all of these skin symptoms that were reported, the associations found between work factors, particularly the frequency of the urine handling and the duration of work (Table 3 and Table 4 ) were almost significant $(P=$ 0.06).

\section{Discussion}

In this study, we evaluated the possible links between skin problems and the handling of urine among people 
Table 4. Incidence rate of skin symptoms reported by farmers using urine-based fertilizer.

\begin{tabular}{|c|c|c|c|}
\hline \multirow{2}{*}{ Variables } & Skin burning & Itching & Paronychia \\
\hline & $\%$ & $\%$ & $\%$ \\
\hline \multicolumn{4}{|c|}{ Duration of work (year) ${ }^{\dagger}$} \\
\hline$<1$ & 10 & 0 & 8.3 \\
\hline $1-3$ & 30 & 40 & 25 \\
\hline$>3$ & 60 & 60 & 66.7 \\
\hline \multicolumn{4}{|c|}{ Frequency in urine handling ${ }^{\dagger}$} \\
\hline$\geq$ Twice per week & 0 & 0 & 0 \\
\hline$\leq$ Twice per week & 100 & 100 & 100 \\
\hline \multicolumn{4}{|c|}{ Personal protective equipment } \\
\hline Yes & 50 & 29 & 41.7 \\
\hline No & 50 & 71 & 58.3 \\
\hline \multicolumn{4}{|l|}{ Farming type } \\
\hline Horticultural & 100 & 100 & 83.3 \\
\hline Ornamental & 0 & 0 & 16.7 \\
\hline \multicolumn{4}{|c|}{ Location of skin symptoms } \\
\hline Hand & 36.3 & 35.7 & 100 \\
\hline Forearm & 27.2 & 50 & 0 \\
\hline Foot & 36.3 & 14.3 & 0 \\
\hline Other & 0 & 0 & 0 \\
\hline
\end{tabular}

${ }^{\dagger} P=0.06$.

involved within productive sanitation systems in Ouagadougou periurban areas. The health symptoms examined were essentially skin burning, itching, eye irritation and paronychia, which can be caused by various agents potentially existing in the work environment. Exposure measurements were based mainly on observations made at any moment by the urine handlers on the workplace (storage site and farm field). We also considered as indicators of risk, data from a previous study on the characterization of chemical ( $\mathrm{pH}$, ammonia, heavy metals) and bacteriological (E. coli, S. aureus, Enterococcus sp.) parameters in the urine of the studied sanitation system [3].

Overall, the results of this study indicate skin symptoms reported by respondents were associated with the work they do. The prevalence of skin problems in the urine site urine handlers was almost the double of that found in farmers handling urine-based fertiliser (Table 2). Yet, according to field observations, the wearing of the personal protective equipment while handling urine was spontaneous among site workers compared to farmers. The handling of the untreated urine (before storage) may have more risk of disease transmission [32]. Based on this assumption, the high prevalence of skin symptoms in handlers of urine on storage sites (compared to farmers) was uncovered. Wearing personal protective equipment did not effectively prevent skin symptoms. This data confirms the observations made at the field regarding protective materials (poor state and unsuitable).

We observed that farmers not handling urine-based fertiliser also reported skin symptoms. Further investigations on the risks faced by farmers in the fields are needed. It is likely that the causes of skin diseases among farmworkers are many. However, some studies suggested that exposure to chemical inputs, e.g. pesticides and fertilisers [14] [33] and irrigation water [8] [34] were the main causes of skin problems self-reported among farmers. Wastewater often used in urban agriculture potentially contains chemical (e.g. heavy metals, pesticide residues) and biological agents (e.g. bacteria, viruses, enzymes) which, in contact with skin can affect it. Farmers interviewed in this study extracted their irrigation water from wells and dams. Regular skin contact with 
water can have a risk of disease because this irrigated water probably contains chemical and biological contaminants from soil or various releases [25] [27] [35]. However, the wearing of personal protective equipment during the handling of chemical inputs and wastewater could minimize the risk of some skin symptoms.

In addition, we observed significant associations between examined skin symptoms and work conditions, particularly the frequency of the urine handling and the duration of work (Table 3 and Table 4). Our field observations showed that all urine handlers complained of strong smells due to ammonia, while the so-called "gas mask" was worn. We also found that there could be phases in the urine handling that are more at risk than others. For example among site urine handlers, exposure risks are high by transporting and decanting urine. In farm, workers using urine-based fertiliser, mix preparation (dilution) are probably the crucial exposure phase. During these all activities, parts of the body not covered such as face, hands and forearms were in frequent contact with aerosols from urine.

Previous studies have shown that the handling of products with high alkalinity ( $\mathrm{pH}>12$ ), exposed people to the risk of skin burning [30] [36]. However, $\mathrm{pH}$ values of the handled urine by targeted actors were less than 9 [3]; therefore, the alkaline effect of urine on the skin of handlers is probably negligible. Also, the concentrations of chromium, lead, copper, cadmium and nickel in the urine were low [3]. So, the implication of heavy metals effects explaining the skin symptoms experienced by the urine handlers can be excluded, as much as the affected body parts (hands, forearms, eyes) were not directly "dipped" in urine during the handling. Moreover, skin irritation due to ammonia can be considered, because of its high concentration in the handled urine and its possible caustic effect on a sweated skin. Based on the above data, it seems clear that the hot and semi-arid climate favoring excessive sweating can be a worsening factor of ammonia toxicity, that also was confirmed by authors [30].

Other associations found in this study are difficult to explain. This is the case of the connection between the occurrence of a paronychia and exposure to the urine-based fertiliser, in the sense that the causative agent is often carried by the subject himself [12] [21]. In this situation, it is necessary that good hygiene practices, including washing the body after work be maintained to prevent some skin diseases.

Few limits to this study can be mentioned. First, respondents were asked to recall the experienced skin symptoms, since the beginning of their work. It is possible that subjective responses have been provided by the surveyed population. In order to minimize these errors due to oversight, Vallejos and et al. [14] asked to farmworkers handling pesticides to recall their skin symptoms reported in the previous seven days before the interview. But, we think that approach to be too limiting the period for recalling health symptoms, potentially hiding some evidence related to exposures. Second, skin problems examined in this study may result from many causes and cannot be solely attributed to the urine exposure. As proof, farmers not handling urine-based fertiliser reported the same skin symptoms that handlers. Third, the method of data collection used do not reflect precise measurements as the severity and the duration of the reported skin symptoms, which are important parameters for assessing effects associated with exposure to hazardous substances. In order to lessen the mentioned limits, we think that conducting longitudinal studies could be necessary, because they analyze in long-term targeted groups. Unfortunately, in the context of the current study, it was difficult to constitute cohorts among the urine handlers since their work was unstable and precarious.

Having a better understanding of factors associated with the occurrence of skin problems can help in efforts to prevent and to treat [14] [37]. Thus, one of the strengths of this study was to provide information on the prevalence of skin symptoms in people exposed to the urine used as fertiliser. The results of this first investigation may call out the people exposed to products possessing a potential health risk (e.g. chemical inputs, excretabased fertilisers) to reinforce personal protective measures. Wearing a suitable protective equipment including coat with long sleeves, gloves covering forearms, boots and goggles, should certainly reduce the risk of skin symptoms here investigated.

\section{Conclusion}

This study suggests the existence of associations between health symptoms such as skin burning, itching, eye irritation and the handling of the urine used as fertiliser. The harmful effect of ammonia on the skin seems predominant compared to other measurable parameters in the handled urine. However, skin symptoms examined in this study could not be exclusively attributed to the urine exposure; other factors inherent to the workplace can be implicated. Based on the data obtained, it is necessary that people involved in the handling of the urine used as fertiliser, have to maintain personal good hygiene practices and wear protective equipment while working to 
reduce the health risks. In order to make our data more incisive and better explore the topic, additional studies are needed. For example, longitudinal studies by monitoring regularly some parameters (e.g. diagnosis, severity and duration of health symptoms) within cohorts, should better assess the effects of ailments due to some exposure. Thus, data from such studies can guide health policy makers, especially in the agricultural sector where the effects associated with exposure to chemical inputs are not well established.

\section{Acknowledgements}

The authors acknowledge the collaboration of the managers of excreta storage sites along productive sanitation systems in Ouagadougou. Furthermore, we wish to give our special thanks to Dr. Marylise Mbakop for the help in the preparation of this study. Finally, we are grateful to the International Foundation for Science (IFS) for the funding source.

\section{References}

[1] Mnkeni, P.N.S., Kutu, F.R., Muchaonyerwa, P. and Austin, L.M. (2008) Evaluation of Human Urine as a Source of Nutrients for Selected Vegetables and Maize under Tunnel House Conditions in the Eastern Cape, South Africa. Waste Management \& Research, 26, 132-139. http://dx.doi.org/10.1177/0734242X07079179

[2] Richert, A., Gensch, R., Jönsson, H., Dagerskog, L., Stenström, T. and Bonzi, M. (2010) Food Security and Productivesanitation: Practical Guideline on the Use of Urine in Crop Production. Sustainable Sanitation Practice, 3, 31-33.

[3] Makaya, J.M., Savadogo, A., Somda, M.K., Bour, J.B., Barro, N. and Traoré, A.S. (2014) Quality of Human Urine Used as Fertilizer: Case of an Ecological Sanitation System in Ouagadougou Peri-Urban Areas-Burkina Faso. Journal of Environmental Protection, 5, 467-474. http://dx.doi.org/10.4236/jep.2014.56049

[4] Dagerskog, L. and Bonzi, M. (2010) Opening Minds and Closing Loops-Productive Sanitation Initiatives in Burkina Faso and Niger. Sustainable Sanitation Practice, 3, 4-11.

[5] World Health Organization (WHO) (2006) Guidelines for the Safe Use of Wastewater, Excreta and Greywater, Vol. 4, Wastewater Use in Agriculture. World Health Organization, Geneva, 196.

[6] Paulsen, E., Skov, P.S. and Andersen, K.E. (1998) Immediate Skin and Mucosal Symptoms from Pot Plants and Vegetables in Gardeners and Greenhouse Workers. Contact Dermatitis, 39, 166-170. http://dx.doi.org/10.1111/j.1600-0536.1998.tb05888.x

[7] Douwes, J., Mannetje, A. and Heederik, D. (2000) Work-Related Symptoms in Sewage Treatment Workers. Annals of Agricultural and Environmental Medicine, 8, 39-45.

[8] Trang, D.T., van der Hoek, W., Tuan, N.D., Cam, P.D., Viet, V.H., Luu, D.D., Konradsen, F. and Dalsgaard, A. (2007) Skin Disease among Farmers Using Wastewater in Rice Cultivation in Nam Dinh, Vietnam. Tropical Medicine and International Health, 12, 51-58. http://dx.doi.org/10.1111/j.1365-3156.2007.01941.x

[9] van der Hoek, W., Anh, V.T., Cam, P.D., Vicheth, C. and Dalsgaard, A. (2005) Skin Diseases among People Using Urban Wastewater in Phnom Penh. UA Magazine, 14, 30-31.

[10] Schenker, M.B., Orenstein, M.R. and Samuels, S.J. (2002) Use of Protective Equipment among California Farmers. American Journal of Industrial Medicine, 42, 455-464. http://dx.doi.org/10.1002/ajim.10134

[11] Mahe, A., Cissé, I.A., Faye, O., N’Diaye, H.T. and Niamba, P. (1998) Skin Diseases in Bamako (Mali). International Journal of Dermatology, 37, 673-676. http://dx.doi.org/10.1046/j.1365-4362.1998.00454.x

[12] Lorette, G., Beaulieu, P.H., Guihard, W., Lemaître, M., Jarlier, N., Bismuth, R., Duru, G. and Janin, N. (2003) Skin Infections in Communities: Bacteria Involved and Sensibility to Antibiotics. Annales de Dermatologie et de Venereologie, 130, 723-731.

[13] Guo, Y.L., Wang, B.J., Lee, C.C. and Wang, J.D. (1996) Prevalence of Dermatoses and Skin Sensitisation Associated with Use of Pesticides in Fruit Farmers of Southern Taiwan. Occupational Environ Medicine, 53, 427-431. http://dx.doi.org/10.1136/oem.53.6.427

[14] Vallejos, Q.M., Schulz, M.R., Quandt, S.A., Feldman, S.R., Galvan, L., Verma, A., Fleischer, A.B., Rapp, S.R. and Arcury, T.A. (2008) Self Report of Skin Problems among Farmworkers in North Carolina. American Journal of Industrial Medicine, 51, 204-212. http://dx.doi.org/10.1002/ajim.20550

[15] Horiuchi, N., Oguchi, S., Nagami, H. and Nishigaki, Y. (2008) Pesticide-Related Dermatitis in Saku Districk, Japan, 1975-2000. International Journal of Occupational and Environmental Health, 14, 25-34. http://dx.doi.org/10.1179/oeh.2008.14.1.25

[16] Pedersen, L.K., Johansen, J.D., Held, E. and Agner, T. (2004) Augmentation of Skin Response by Exposure to a Combination of Allergens and Irritants-A Review. Contact Dermatitis, 50, 265-273. 
http://dx.doi.org/10.1111/j.0105-1873.2004.00342.x

[17] Lynde, C.B., Obadia, M., Liss, G.M., Ribeiro, M., Holness, D.L. and Tarlo, S.M. (2009) Cutaneous and Respiratory Symptoms among Professional Cleaners. Occupational Medicine, 59, 249-254. http://dx.doi.org/10.1093/occmed/kqp051

[18] Suskind, R.R. (1977) Environment and the Skin. Environmental Health Perspectives, 20, 27-37. http://dx.doi.org/10.1289/ehp.772027

[19] Thyssen, J.P., Johansen, J.D., Linneberg, A. and Menné, T. (2010) The Epidemiology of Hand Eczema in the General Population-Prevalence and Main Findings. Contact Dermatitis, 62, 75-87. http://dx.doi.org/10.1111/j.1600-0536.2009.01669.x

[20] Smedley, J., Williams, S., Peel, P. and Pedersen, K. (2012) Management of Occupational Dermatitis in Healthcare Workers: A Systematic Review. Occupational and Environmental Medicine, 69, $276-279$. http://dx.doi.org/10.1136/oemed-2011-100315

[21] Larson, E.L., Hughe, C.A. and Pyrek, J.D. (1998) Changes in Bacterial Flora Associated with Skin Damage on Hands of Healthcare Personnel. American Journal of Infection Control, 26, 513-521. http://dx.doi.org/10.1016/S0196-6553(98)70025-2

[22] Gong, J.Q., Lin, L. and Lin, T. (2006) Skin Colonization by Staphylococcus aureus in Patients with Eczema and Atopic Dermatitis and Relevant Combined Topical Therapy: A Double Blind Multicentre Randomized Controlled Trial. British Journal of Dermatology, 155, 680-687. http://dx.doi.org/10.1111/j.1365-2133.2006.07410.x

[23] Harbarth, S., Liassine, N., Dharan, S., Herrault, P., Auckenthaler, R. and Pittet, D. (2000) Risk Factors for Persistent Carriage of Methicillin-Resistant Staphylococcus aureus. Clinical Infectious Diseases, 3, 1380-1385. http://dx.doi.org/10.1086/317484

[24] Wertheim, H.F.L., Melles, D.C., Vos, M.C., van Leeuwen, W., van Belkum, A. and Verbrugh, H.A. (2005) The Role of Nasal Carriage in Staphylococcus aureus Infections. The Lancet Infectious Diseases, 5, 751-762. http://dx.doi.org/10.1016/S1473-3099(05)70295-4

[25] Sou, Y.M. (2009) Recycling Wastewater for Irrigation: Fertilizing Potential, Health Risks and Impacts on Soil Quality. Ph.D. Dissertation, EPF Lausanne, Lausanne.

[26] Dianou, D., Savadogo, B., Zongo, D., Zougouri, T., Poda, J.N., Bado, H. and Rosillon, F. (2011) Surface Waters Quality of the Sourou Valley: The Case of Mouhoun, Sourou, Debe and Gana Rivers in Burkina Faso. International Journal of Biological and Chemical Sciences, 5, 1571-1589.

[27] Nitiema, L.W., Savadogo, B., Zongo, D., Kaboré, A., Poda, J.N., Traoré, A.S. and Dianou, D. (2013) Microbial Quality of Wastewater Used in Urban Truck Farming and Health Risks Issues in Developing Countries: Case Study of Ouagadougou in Burkina Faso. Journal of Environmental Protection, 4, 575-584. http://dx.doi.org/10.4236/jep.2013.46067

[28] Bassolé, D. and Ouédraogo, L. (2007) Problem of the Use of Pesticides in Crop Conservation and Truck Farming in Urban and Peri-Urban Areas, Burkina Faso. International Fertilizer Development Center, IFDC, 51 p.

[29] Agency for Toxic Substances and Disease Registry, ATSDR (2004) Toxicological Profiles for Ammonia. US Department of Health and Human Services, Public Health Services, Atlanta. http://www.atsdr.cdc.gov/toxpro2.html

[30] Blanco, L.E., Aragon, A., Lundberg, I. and Lidén, C. (2005) Determinants of Dermal Exposure among Nicaraguan Subsistence Farmers during Pesticide Applications with Backpack Sprayers. Annals of Occupational Hygiene, 49, 17-24.

[31] Beare, J.D., Wilson, R.S. and Marsh, R.J. (1988) Ammonia Burns of the Eye: Old Weapon in New Hands. British Medicine Journal, 296, 590. http://dx.doi.org/10.1136/bmj.296.6622.590

[32] Jönsson, H. and Vinnerås, B. (2007) Experiences and Suggestions for Collection Systems for Source-Separated Urine and Faeces. Water Science and Technology, 56, 71-76. http://dx.doi.org/10.2166/wst.2007.558

[33] Strong, L.L., Thompson, B., Coronado, G.D., Griffith, W.C., Vigoren, E.M. and Islas, I. (2004) Health Symptoms and Exposure to Organophosphate Pesticides in Farmworkers. American Journal of Industrial Medicine, 46, 599-606. http://dx.doi.org/10.1002/ajim.20095

[34] Shrutakirthi, S.D., Suraj, D., Sugandhi, R., Girija, R. and Sreekumaran, N. (2005) Dermatoses among Paddy Field Workers-A Descriptive, Cross-Sectional Pilot Study. Indian Journal of Dermatology, Venereology and Leprology, 71, 254258. http://dx.doi.org/10.4103/0378-6323.16617

[35] Cissé, G. (1997) Health Impact of Wastewater Utilization in Urban Agriculture: Case of Truck Farming in Ouagadougou. Ph.D. Dissertation, EPF Lausanne, Lausanne.

[36] Géraut, C. and Frimat, P. (1993) Dermatoses in Cement Users. Archives des Maladies Professionnelles, 54, 312-314.

[37] Susitaival, P., Flyvholm, M.A. and Meding, B. (2003) Nordic Occupational Skin Questionnaire (NOSQ-2002): A New Tool for Surveying Occupational Skin Diseases and Exposure. Contact Dermatitis, 49, 70-76. http://dx.doi.org/10.1111/j.0105-1873.2003.00159.x 
Scientific Research Publishing (SCIRP) is one of the largest Open Access journal publishers. It is currently publishing more than 200 open access, online, peer-reviewed journals covering a wide range of academic disciplines. SCIRP serves the worldwide academic communities and contributes to the progress and application of science with its publication.

Other selected journals from SCIRP are listed as below. Submit your manuscript to us via either submit@scirp.org or Online Submission Portal.
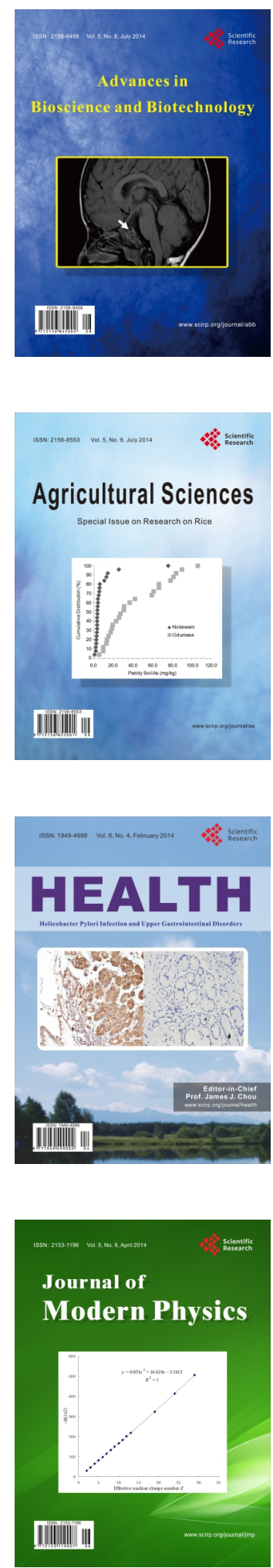
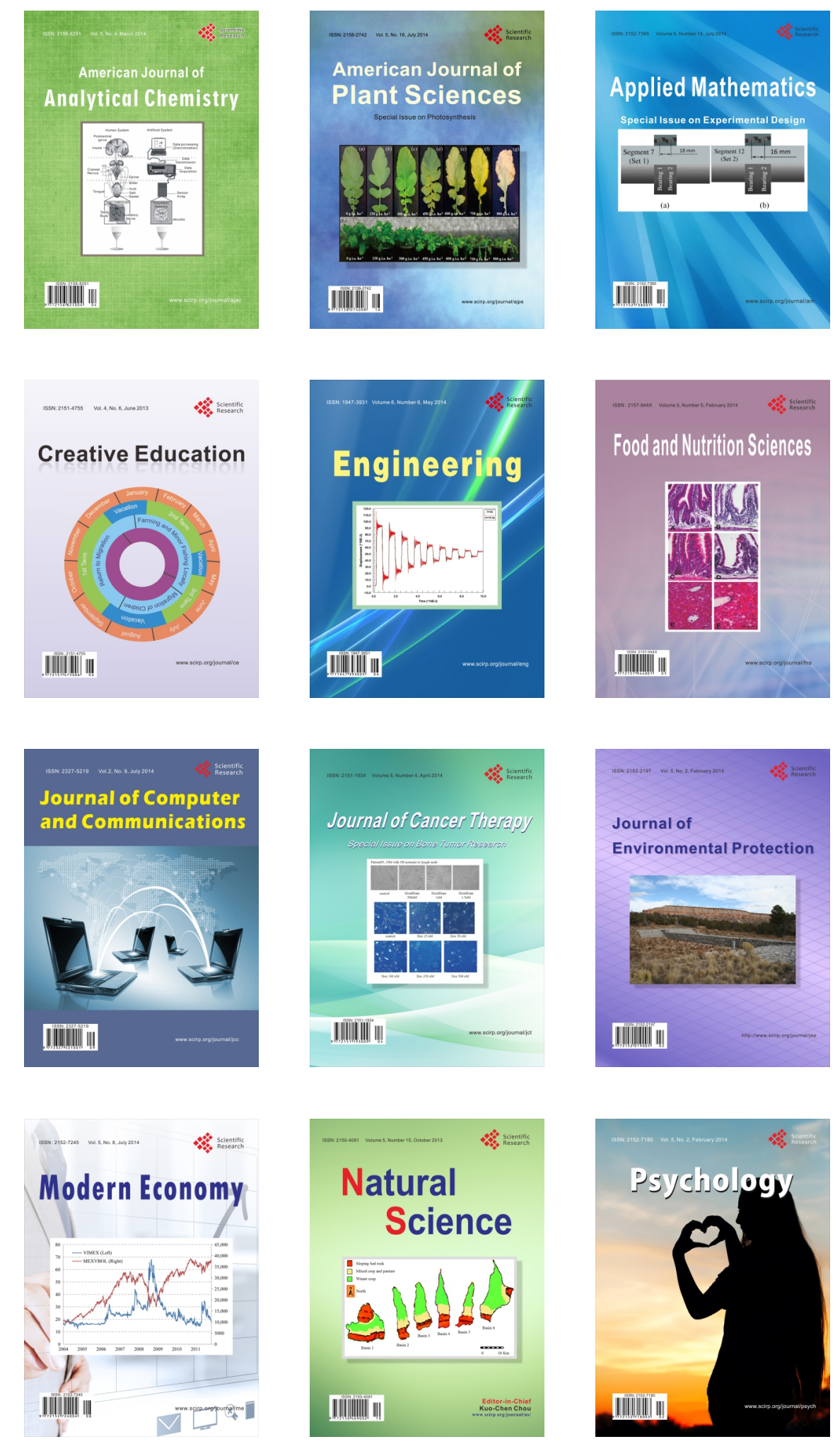